\title{
PERGESERAN KOMPETENSI ABSOLUT PTUN DALAM SISTEM HUKUM INDONESIA
}

\author{
Despan Heryansyah \\ Pascasarjana Fakultas Hukum UII Yogyakarta \\ Email:despan.her@gmail.com
}

\begin{abstract}
Abstrak
Keberadaan diskresi disatu sisi memang memberikan manfaat bagi pejabat administrasi untuk mengatasi stagnasi pemerintahan. Diskresi memungkinkan seorang pejabat pemerintahan untuk mengeluarkan kebijakan meskipun tidak ada peraturan perundang-undangan yang menjadi payung hukum dikeluarkannya kebijakan itu. Namun di sisi lain, diskresi apabila tidak digunakan sesuai dengan prosedur dan persyaratan yang telah ditentukan akan membuka peluang terjadinya penyalahgunaan wewenang oleh pejabat pemerintahan, yang tentu saja akan merugikan warga negara sebagai korbannya. Permasalahan dalam penelitian ini adalah, pertama, benarkah diskresi menjadi buah simalakama terhadap penyelenggaraan pemerintahan. Kedua, Bagaimana problematika penerapan diskresi dalam peraturan perundang-undangan di Indonesia pasca UU No 30 Tahun 2014 tentang Administrasi Pemerintahan. Penelitian ini merupakan penelitian doctrinal yang menggunakan bahan hukum primer dan bahan hukum sekunder. Metode pendekatan yang digunakan yakni pendekatan normatif. Hasil penelitian menyimpulkan bahwa, petama, diskresi telah menjadi buah simalakama penyelenggaraan pemerintahan karena di satu sisi dapat mengatasi stagnasi pemerintahan namun di sisi lain membuka peluang terjadinya penyalahgunaan wewenang. Kedua, ada banyak masalah yang ditimbulkan pasca disahkannya UU No 30 Tahun 2014 tentang Administrasi Pemerintahan khususnya yang berkaitan dengan diskresi.
\end{abstract}

Kata Kunci: Kompetensi Absolut; Diskresi; Penyalahgunaan Wewenang

\begin{abstract}
The existence of a discretion on the one hand provides benefits for administrative officials to overcome the stagnation of government. A discretion may enable a government official to issue a policy although there is no legislation as its legal protection. On the other hand, a discretion will open opportunities for abuse of authority by government officials if it is not used in accordance with the procedures and requirement determined, which certainly will harm citizens as the victims. The problems in this research are whether it is true that discretion is "between the devil and the blue sea" towards governance and how the problem of discretion application is in the laws and regulations in Indonesia after Law No. 30 Year of 2014 on Government Administration. This research was a doctrinal research using primary and secondary law material. The approach method used was normative approach. The result of the
\end{abstract}


research concludes that, firstly, discretion has become "between the devil and the blue sea" of governance because in one side it can overcome the stagnation of government, but it opens opportunities for abuse of authority, and, secondly, there are many problems caused after the enactment of Law No. 30 Year of 2014 on Government Administration related to discretion.

Keywords: Absolute Competence; Discretion; Misuse Authority

\section{A. PENDAHULUAN}

Pemikiran atau konsepsi manusia merupakan anak zaman yang lahir dan berkembang dalam situasi kesejarahan dengan berbagai pengaruhnya. Pemikiran atau konsepsi manusia tentang negara hukum juga lahir dan berkembang dalam situasi kesejarahan (Ridwan HR, 2011: 1). Konsepsi negara hukum mengalami perkembangan yang cukup pesat, pada mulanya seluruh kekuasaan negara diserahkan kepada seorang raja yang membentuk undang-undang, menjalankan pemerintahan serta menjalankan fungsi peradilan secara lansung. Keputusan tertinggi berada di tangan raja, sehingga apapun yang menjadi keputusan raja harus dijalankan dengan berbagai konsekuensinya. Bahkan pada masa awal-awal abad pertengahan, kekuasaan raja disandingkan dengan kekuasaan Tuhan, keputusan raja adalah kehendak Tuhan. Sadar bahwa konsep ini semakin menjadikan raja sewenang-wenang terhadap warga negara maka kekuasaan raja mulai dikurangi melalui lahirnya magna charta, sebuah perjanjian antara Raja John Inggris dengan para Bangsawan yang pada pokoknya berisi pemberian hak-hak kepada para bangsawan dan pengurangan kekuasaan yang dimiliki oleh Raja. Konsepsi tentang negara terus mengalami perkembangan hingga pada perjanjian Montevideo, pembagian kekuasaan oleh John Locke, dilanjutkan Montesqiueu dalam bukunya L'Esprit des Lois, hingga kemudian berkembanglah model negara hukum formal.

Negara hukum formal pun hanya bertahan beberapa waktu dan dianggap sudah tidak relevan lagi karena hanya menjadikan negara sebagai penjaga malam saja, yang tidak memiliki kewenangan mencampuri semua urusan warna negara. Kemudian munculah konsep negara hukum modern yang menempatkan pemerintah sebagai pihak yang bertanggung jawab atas kesejahteraan rakyatnya (Marbun, 2011: 189). Ciri utama negara ini adalah munculnya kewajiban pemerintah untuk mewujudkan kesejahteraan umum bagi warga negaranya (Ridwan HR, 2011: 14).

Pemikiran tentang negara hukum ini mencapai puncaknya pada abad ke-19 dengan munculnya konsep rechtstaat dari Freidrich Julius Stahl, yang diilhami oleh pemikiran Immanuel Khant. Menurut Stahl unsur-unsur negara hukum adalah sebagai berikut: (1) Perlindungan hak-hak asasi manusia; (2) Pemisahan atau pembagian kekuasaan untuk menjamin hak-hak itu; (3) Pemerintahan berdasarkan peraturan perundang-undangan; dan (4) Peradilan administrasi dalam perselisihan (Hadjon, 1987: 16-82). Dalam ketentuan yang lebih jelas, dalam karyanya Die Philosophie des Recht, ia mengungkapkan beberapa unsur negara hukum yang kemudian menjadi ciri utama negara hukum rechtsstaat, yaitu (Hadjon, 1987: 1682): (1) Mengakui dan melindungi Hak Asasi Manusia; (2) Untuk melindungi 
terhadap hak asasi tersebut maka penyelenggaraan negara harus berdasarkan atas teori trias politica; (3) Dalam menjalankan tugasnya, pemerintah berdasarkan atas undang-undang (wetmatigbestuur); (4) Jika dalam menjalankan tugasnya berdasarkan undang-undang, pemerintah mash melanggar hak asasi (campur tangan pemerintah dalam kehidupan pribadi), maka ada pengadilan administrasi yang akan menyelesaikannya. Sementara pada wilayah Anglo-Saxon, muncul pula konsep negara hukum (rule of law) dari A.V. Dicey, dengan unsur-unsur sebagai berikut: (1) Supremasi aturan-aturan hukum (Supremacy of the law); (2) Kedudukan yang sama dalam menghadapi hukum (equality before the law); (3) Terjaminnya hak-hak manusia oleh undang-undang (Dicey, 1973: 202).

Adanya unsur "peradilan administrasi dalam pemerintahan" pada konsep rechstaat, dan ketiadaannya pada konsep rule of law unsur merupakan perbedaan yang sangat mendasar dari kedua konsep negara hukum ini. Keberadaan peradilan administrasi dalam konsep rechstaat ini dilatarbelakangi oleh kewenangan pemerintah dalam menormakan segala peraturan dalam bentuk peraturan perundang-undangan, maka disediakan peradilan administrasi sebagai wadah bagi masyarakat untuk mencari keadilan.

Selain itu, karakteristik paling mendasar dari tindakan hukum yang dilakukan oleh pemerintah adalah keputusan-keputusan dan ketetapan yang bersifat sepihak (Hadjon, 1987: 124). Dikatakan sepihak karena dilakukan tidaknya suatu tindakan hukum pemerintah itu tergantung pada kehendak sepihak dari pemerintah. Keputusan dan ketetapan sebagai instrumen hukum pemerintah dalam melakukan tindakan hukum sepihak, dapat menjadi penyebab terjadinya pelanggaran hukum bagi warga negara, apalagi dalam negara hukum modern yang memberikan kewenangan yang luas kepada pemerintah untuk mencampuri kehidupan warga negara. Oleh karena itu diperlukan perlindungan hukum bagi warga negara terhadap tindakan hukum pemerintah (Ridwan, 2002: 226). Oleh karena itu dibentuklah peradilan administrasi, agar rakyat mendapatkan kepastian hukum dalam mencari keadilan.

Kedudukan Peradilan Tata Usaha Negara (PTUN) dalam UUD Neraga RI 1945 pasca amandemen telah diatur secara tegas, Khusunya dalam Pasal 24 Ayat (2) UUD 1945. Pengaturan secara tegas kedudukan Peradilan Tata Usaha Negara (PTUN) secara tegas dalam konstitusi tersebut dipengaruhi oleh gagasan mengenai perlunya peningkatan kualitas pengawasan terhadap pemerintah. Karena potensi untuk terjadinya penyalahgunaan wewenang dari pejabat pemerintah semakin besar yang jelas merugikan masyarakat umum (Tjandra, 2009: 1). Ketentuan mengenai hukum materil dan hukum formil dari Peradilan Tata Usaha Negara ini kemudian diatur dalam UU No 5 Tahun 1986 tentang Peradilan Tata Usaha Negara.

Kompetensi absolut dari PTUN terdapat dalam pasal 47 UU PTUN yang menentukan bahwa pengadilan bertugas dan berwenang memeriksa, memutus dan menyelesaikan sengketa tata usaha negara. Yang dimaksud dengan sengketa tata usaha negara tersebut, menurut Pasal 1 angka 4 adalah sengketa yang timbul dalam bidang tata usaha negara antara orang atau badan hukum perdata dengan badan 
atau pejabat tata usaha negara, baik di pusat maupun di daeah, sebagai akibat dikeluarkannya Keputusan Tata Usaha Negara, termasuk sengketa kepegawaian berdasarkan peraturan perundang-undangan yang berlaku (Wiyono, 2007: 5).

Dari ketentuan dalam UU No 5 Tahun 1986 ini terlihat bahwa kompetensi PTUN sangat sempit, hanya berkaitan dengan Keputusan Tata Usaha Negara yang dinilai merugikan masyarakat. Keputusan sebagaimana diketahui harus bersifat konkret, individual dan final, selain dari pada itu PTUN tidak memiliki kewenangan untuk mengadilinya. Kondisi di atas berjalan hingga hampir 20 tahun, kemudian sejalan dengan semakin meningkatnya tugas-tugas yang harus dilaksanakan oleh pemerintah yang dipengaruhi oleh paham negara kesejahteraan (walfare state). Ditambah lagi dengan kewenangan pemerintah untuk melakukan diskresi, yaitu kebebasan untuk mengambil kebijakan apabila tidak ada UU yang mengaturnya atau UU samar yang dimiliki oleh pemerintah. Oleh karena itu, kompetensi PTUN yang terdapat di dalam UU No 5 Tahun 1986 dirasa sudah tidak relevan lagi, karena terlalu sempit hanya mengadili keputusan yang bersifat konkrit, individual dan final saja.

Maka untuk memperluas perlindungan hukum kepada masyarakat agar tidak menjadi korban kesewenang-wenangan pemerintah, pada tahun 2014 disahkan UU No 30 Tahun 2014 tentang Administrasi Pemerintahan. UU ini memperluas kompetensi PTUN yang tidak lagi hanya mengadili Keputusan Tata Usaha Negara saja namun juga diberikan kewenangan untuk mengadili perkara lain dalam kaitannya dengan administrasi negara. PTUN diberikan kewenangan untuk mengadili apakah dalam keputusan atau tindakan pejabat tata usaha negara terdapat penyalahgunaan wewenang atau tidak. Perluasan kompetensi absolut PTUN ini tentu saja menimbulkan akibat hukum tersediri baik secara formil ataupun materil, dan dalam prakteknya juga terdapat masalah-masalah baru yang timbul akibat perluasan itu. Oleh karena itu, perlu bagi penulis untuk mengkajinya lanjut dalam tulisan ini.

Berdasarkan pada uraian di atas, maka kajian ini merumuskan beberapa masalah, yaitu:

1. Bagaimanakah bentuk pergeseran kompetensi absolut Peradilan Tata Usaha Negara dalam UU No 30 Tahun 2014?

2. Apakah implikasi dari pergeseran kompetensi absolut Peradilan Tata Usaha Negara?

\section{B. METODE PENELITIAN}

Penelitian ini merupakan penelitian hukum doktrinal, objek utama yang penulis kaji adalah undang-undang dengan menggunakan teori-teori dari para ahli sebagai pisau analisis. Bahan hukum yang digunakan adalah bahan hukum primer dan bahan hukum sekunder. Adapun metode pendekatan yang digunakan yakni pendekatan yuridis-normatif. Bahan hukum yang telah penulis kumpulkan kemudian dianalisis secara deskriptif kualitatif kemudian disistematisasi menurut urutan dan pengelompokkan yang telah ditentukan sebelumnya. 


\section{PEMBAHASAN}

\section{Kompetensi Absolut Hukum PTUN Menurut UU No 5 Tahun 1986}

Pada umumnya dalam hukum acara dikenal adanya kewenangan (konpetensi) suatu badan peradilan untuk memeriksa dan mengadili suatu perkara. Kompetensi tersebut dibedakan atas kompetensi relatif dan kompetensi absolut. Kompetensi relatif adalah kewenangan pengadilan untuk mengadili suatu perkara sesuai dengan wilayah hukumnya, sedangkan kompetensi absolut adalah kewenangan pengadilan sesuai dengan objek atau materi atau pokok sengketanya (Marbun, 2011: 239). Namun yang akan penulis bahas dalam tulisan ini adalah mengenai kompetensi absolut peradilan administrasi.

Kompetensi absolut berhubungan dengan kewenangan PTUN memeriksa dan mengadili suatu sengketa menurut objek atau materi atau pokok sengketa. Meskipun badan/pejabat tata usaha negara dapat digugat di PTUN, tetapi tidak semua tindakannya dapat diadili oleh PTUN.

Tindakan badan/pejabat tata usaha negara yang dapat digugat di PTUN diatur dalam Pasal 1 butir (3) dan Pasal 3 UU No 5 Tahun 1986, sedangkan tindakan selebihnya menjadi kompetensi Peradilan Umum atau Peradilan Tata Usaha Militer atau bahkan untuk masalah pembuatan peraturan (regeling) yang dibuat oleh pemerintah dan bersifat umum, kewenangan untuk mengadilinya berada pada Mahkamah Agung melalui Hak Uji Materil (Marbun, 2011: 41).

Pasal 47 UU No 5 Tahun 1986 menyebutkan: pengadilan bertugas dan berwenangan memeriksa, memutuskan dan menyelesaikan sengketa tatausaha negara. Apakah yang dimaksud dengan sengketa tata usaha negara? Pasal 1 angka 4 UU No 5 Tahun 1986 juga merumuskan sengketa yang timbul dalam bidang tata usaha negara, baik dipusat maupun di daerah, sebagai akibat dikeluarkannya keputusan tata usaha negara, termasuk sengketa kepegawaian berdasarkan peraturan perundang-undangan yang berlaku (Hadjon, 1999: 318).

Dengan demikian, KTUN merupakan dasar lahirnya sengketa tata usaha negara. Apakah KTUN itu Pasal 1 angka 3 merumuskan KTUN adalah suatu penetapan tertulis yang dikeluarkan oleh badan atau pejabat tata usaha negara yang berisi tindaka hukum tata usaha negara yang berdasarkan peraturan perundangundangan yang berlaku yang bersifat konkret, individual dan final, yang menimbulkan akibat hukum bagi seseorang atau badan hukum perdata.

Elemen-elemen di atas belum menjadikan pengertian KTUN tuntas. Ternyata masih ditambah lagi dengan hal-hal yang tercantum dalam pasal 3, yaitu dalam hal suatu badan atau pejabat tata usaha negara tidak mengeluarkan suatu keputusan yang dimohonkan kepadanya, sedang hal itu merupakan kewajibannya (Hadjon, 1999: 319). Jangka waktu yang ditentukan empat bulan sejak permohonan diterima, jika peraturan perundang-undangan tidak menentukannya. 
Meskipun suatu keputusan tata usaha negara telah memenuhi unsur-unsur dan atau ciri sebagaimana disebut dalam Pasal 1 angka (3), tetapi ada putusan yang tidak dapat dimasukkan sebagai kompetensi PTUN, sehingga tidak dapat dijadikan objek sengketa tata usaha negara. Beberapa pembatasan tersebut ditemukan dalam Pasal 2, Pasal 48, Pasal 49, Pasal 142 dan penjelasan Umum UU No 5 Tahun 1986. Sjachran Basah mengelompokkan pembatasan itu menjadi dua golongan, yaitu pembatasan lansung dan pembatasan tidak lansung (Marbun, 2011: 242-245).

Pertama, pembatasan langsung adalah pembatasan yang tidak memungkinkan sama sekali bagi PTUN untuk memeriksa dan memutus sengketa tersebut. Pembatasan langsung ini terdapat di Pasal 2, Pasal 49, Penjelasan Umum. Menurut Pasal 2, yang tidak termasuk dalam Keputusan Tata Usaha Negara adalah: (1) Keputusan tata usaha negara yang merupakan pengaturan yang bersifat umum; (2) Keputusan tata usaha negara yang merupakan perbuatan hukum perdata; (3) KTUN yang masih memerlukan persetujuan; (4) KTUN yang dikeluarkan berdasarkan KUHP dan KUHAP dan peraturan perundang-undangan lain yang bersifat hukum pidana; (5) KTUN yang dikeluarkan berdasarkan atas hasil pemeriksaan badan peradilan atas ketentuan peraturan perundang-undangan yang berlaku; (6) KTUN mengenai ABRI (sekrang TNI); (7) Keputusan Panitia Pemilihan baik di pusat maupun di daerah mengenai hasil pemilihan umum.

Selanjutnya menurut Pasal 49 yang berbunyi:

PTUN tidak berwenang memeriksa, memutuskan, dan menyelesaikan sengketa tata usaha negara tertentu dalam hal keputusan tata usaha negara yang disengketakan itu dikeluarkan:

a. dalam waktu perang, keadaan bahaya, keadaan bencana alam atau keadaan luar biasa yang membahayakan berdasarkan peraturan perundang-undangan yang berlaku;

b. dalam keadaan mendesak untuk kepentingan umum berdasarkan peraturan perundang-undangan yang berlaku.

Sedangkan menurut penjelasan umum angka (1) sengketa administrasi di lingkungan Angkatan Bersenjata dan dalam soal-soal militer yang menurut ketentuan UU No 26 Tahun 1953 dan UU No 19 Tahun 1958 diperiksan, diputus dan diselesaikan oleh Peradilan Tata Usaha Militer.

Kedua, pembatasan tidak langsung adalah pembatasan atas kompetensi absolut yang masih membuka kemungkinan bagi PTUN tingkat banding, untuk memeriksa dan memutus sengketa tata usaha negara dengan ketentuan bahwa seluruh upaya administrasi yang tersedia untuk itu telah di tempuh (Pasal 48 UU No 5 1986). Berdasarkan pembatasan tidak lansung ini berarti sengketa harus terlebih dahulu diselesaikan lebih dahulu melalui upaya administrasi. Apabila upaya administrative telah ditemput namun penggugat belum juga merasa puas, maka gugatan dapat lansung diajukan ke Pengadilan Tinggi TUN.

Kembali ke permasalahan sengketa tata usaha negara, dari ketentuan di atas, dapat diketahui bahwa yang dimaksud dengan sengketa tata usaha negara terdiri dari beberapa unsur, yaitu: (1) Sengketa yang timbul dalam bidang tata usaha negara; (2) Sengketa tersebut antara orang atau badan hukum perdata dengan 
Badan atau Pejabat Tata Usaha Negara; (3) Sengketa yang dimaksud sebagai akibat dikeluarkannya Keputusan Tata Usaha negara.

Penjelasan Pasal 1 angkat (4) menyebutkan bahwa istilah "sengketa" yang dimaksudkan dari ketentuan yang terdapat dalam Pasal 1 angkat (4) mempunyai arti khusus sesuai dengan fungsi Peradilan Tata Usaha Negara. Mengenai apa yang dimaksud dengan "Tata Usaha Negara”, Pasal 1 Angka 1 menentukan bahwa Tata Usaha Negara adalah Administrasi Negara yang melaksanakan fungsi untuk menyelenggarakan urusan pemerintahan, baik di tingkat pusat maupun di Daerah (Riyono, 2007: 5-6).

Adapun yang dimaksud dengan "urusan pemerintahan" dalam Pasal 1 Angka 1, oleh penjelasan Pasal 1 Angka 1 disebutkan sebagai kegiatan yang bersifat eksekutif. Jika berbicara tentang kegiatan eksekutif, mau tidak mau kita harus berbicara pula tentang teori Trias Politika dari Montesquieu, yaitu bahwa kekuasaan negara dibagi menjadi tiga bagian:

1. Legislatif, yaitu kekuasaan yang membuat peraturan perundang-undangan;

2. Eksekutif, yaitu kekuasaan yang melaksanakan peraturan;

3. Yudikatif, yaitu kekuasaan yang mengawasi/mengadili pelanggaran terhadap peraturan tersebut.

Jadi, jika ditinjau dari sudut teori trias politika, dapat diketahui bahwa yang dimaksud dengan "kegiatan yang bersifat eksekutif" adalah kegiatan yang bersifat pelaksanaan undang-undang. Pertanyaannya adalah apakah Tata Usaha Negara itu hanya melaksanakan fungsi untuk menyelenggarakan kegiatan yang bersifat pelaksanaan peraturan perundang-undangan saja?

Secara praktik, tata usaha negara tidak hanya melaksanakan fungsi untuk menyelenggarakan kegiatan yang bersifat pelaksanaan peraturan perundangundangan, tetapi juga melaksanakan fungsi untuk menyelesaikan urusan pemerintahan yang penting dan mendesak yang belum diatur dalam peraturan perundang-undangan, misalnya dalam menghadapi terjadinya bencana (banjir, gempa bumi, dan sebagainya). Pada dasarnya pemerintah tidak hanya melaksanakan UU, tetapi atas dasar "freies ermessen" dapat pula melakukan perbuatan-perbuatan lainnya meskipun belum diatur secara tegas oleh undangundang (Hadjon, 1999: 138).

Namun ada dilema tersendiri berkaitan dengan freies ermessen ini, karena segala kebijakan pejabat tata usaha negara yang tertuang dengan alasan freies ermessen atau diskresi, tidak ada ketentuan yang mengatur tentang pengujiannya. Termsuk UU No 5 Tahun 1986 ini juga tidak mangatur, sehingga PTUN merasa tidak memiliki kompetensi untuk memeriksa, memutus dan menyelesaikannya. Padahal di sisi yang lain, potensi terjadi penyalahgunaan wewenang dengan adanya diskresi ini malah lebih besar lagi.

Kemudian telah disebutkan oleh Pasal 1 Angka 4 bahwa yang juga menjadi kewenangan PTUN adalah "sengketa kepegawaian berdasarkan peraturan perundang-undangan yang berlaku". Pertanyaannya kemudian, apa yang dimaksud 
dengan sengketa kepegawaian berdasarkan peraturan perundang-undangan yang berlaku?

Pasal 5 UU No 8 Tahun 1974 menentukan, penyelesaian sengketa di bidang kepegawaian dilakukan melalui peradilan, untuk itu sebagai bagian dari tata usaha negara yang dimaksud dalam UU No 14 Tahun 1970 tentang Ketentuan-ketentuan Pokok Kekuasaan Kehakiman. Dari ketentuan tersebut dapat diketahui bahwa sebelum UU No 8 Tahun 1970 diubah dengan UU No 43 Tahun 1999 pembentuk UU mempunyai kehendak untuk membentuk pengadilan kepegawaian sebagai peradilan khusus di lingkungan PTUN (Wiyono, 2007: 8).

Akan tetapi dengan diadakannya perubahan UU No 8 Tahun 1974 dengan UU No 43 Tahun 1999, tetnyata kehendak pembentukan UU tersebut berubah, karena Pasal 35 UU No 8 Tahun 1974 diubah menjadi tiga Ayat, yang pada Ayat (1) nya menentukan "sengketa kepegawaian diselesaikan melalui Peradilan Tata Usaha Negara". Dengan demikian, dapat diketahui bahwa yang dimaksud dengan "sengketa kepegawaian berdasarkan peraturan perundang-undangan yang berlaku" dalam perumusan ketentuan yang terdapat dalam Pasal 1 Angka (4) adalah sengketa kepegawaian berdasarkan UU No 8 Tahun 1974 Jo. UU No 43 Tahun 1999.

Dengan berpedoman pada pengertian tentang sengketa Tata Usaha Negara seperti yang terdapat dalam Pasal 1 Angka (4), maka yang dimaksud dengan sengketa kepegawaian adalah sengkata yang timbul dalam bidang Tata Usaha Negara antara orang yang menduduki jabatan sebagai Pegawai Negeri dengan Badan atau Pejabat Tata Usaha Negara, baik di pusat maupun di daerah sebagai akibat dikeluarkannya Keputusan Tata Usaha Negara di bidang kepegawaian.

\section{Pergeseran Kompetensi Absolut PTUN}

Sesuai dengan ketentuan Pasal 1 ayat (2) UUD Negara Republik Indonesia Tahun 1945, kedaulatan berada di tangan rakyat dan dilaksanakan menurut Undang-Undang Dasar. Selanjutnya menurut ketentuan Pasal 1 ayat (3) UUD NRI Tahun 1945, negara Indonesia adalah negara hukum. Hal ini berarti bahwa penyelenggaraan pemerintahan negara republik Indonesia harus berdasarkan atas prinsip kedaulatan rakyat dan prinsip negara hukum. berdasarkan prinsip-prinsip tersebut, segala bentuk keputusan dan/atau tindakan administrasi pemerintahan harus berdasarkan atas kedaulatan rakyat dan hukum yang merupakan refleksi dari pancasila sebagai ideologi negara. Dengan demikian tidak berdasarkan kekuasaan yang melekat pada kedudukan penyelanggaraan pemerintahan itu sendiri.

Semakin luasnya kewenangan yang dimiliki oleh pemerintah sebagai akibat dari penerapan konsepsi negara kesejahteraan (walfare state), akan semakin membuka potensi terjadinya penyalahgunaan wewenang. Tentu yang akan menjadi korbannya adalah rakyat, oleh karena itu perlu perngaturan yang tegas berkaitan dengan administrasi pemerintahan agar rakyat memiliki kepastian hukum dan terhindar dari korban penyalahgunaan wewenang penguasa. Berkaitan dengan hal tersebut, maka pada tahun 2014 lahirlah Undang-Undang Administrasi yang pertama di Indonesia yaitu UU No 30 Tahun 2014 tentang Administrasi Pemerintahan. 
Meski mendapatkan banyak kritik dari berbagai kalangan karena banyak terdapat kontradiksi dan kerancuan, namun karena UU tersebut telah disahkan dalam Lembaran Negara maka wajib untuk ditaati oleh seluruh warga negara. UU ini mengatur banyak ketentuan pelaksanaan administrasi di Indonesia, termasuk menggeser kompetensi Peradilan Tata Usaha Negara. PTUN dalam UU No 5 Tahun 1986 hanya memiliki wewenang untuk mengadili Keputusan (beshicking) yang dikeluarkan oleh pemerintah (eksekutif) dan sengketa kepegawaian saja. Namun dalam UU No 30 Tahun 2014 ini PTUN memiliki kompetensi absolut yang lebih luas lagi. Bentuk pergeseran dalam UU No 30 Tahun 2014 ini yaitu:

\section{a. Ruang Lingkup Administrasi}

Kalau pada UU No 5 Tahun 1986, ruang lingkup administrasi hanya pada bidang eksekutif saja, yaitu pelaksana undang-undang dan dalam prakteknya ditambah dengan kewenangan pejabat pemerintah untuk mengeluarkan diskresi. Namun dalam UU No 30 Tahun 2014 ini terdapat perluasan ruang lingkup administrasi, selain tetap mempertahankan administrasi pada bidang eksekutif juga ditambah dengan administrasi pada bidang kekuasaan yang lain. Dalam Pasal 4 disebutkan:

1) Ruang lingkup pengaturan Administrasi Pemerintahan dalam UndangUndang ini meliputi semua aktivitas:

a) Badan dan/atau Pejabat Pemerintahan yang menyelenggarakan Fungsi Pemerintahan dalam lingkup lembaga eksekutif;

b) Badan dan/atau Pejabat Pemerintahan yang menyelenggarakan Fungsi Pemerintahan dalam lingkup lembaga yudikatif;

c) Badan dan/atau Pejabat Pemerintahan yang menyelenggarakan Fungsi Pemerintahan dalam lingkup lembaga legislatif; dan

d) Badan dan/atau Pejabat Pemerintahan lainnya yang menyelenggarakan Fungsi Pemerintahan yang disebutkan UndangUndang Dasar Negara Republik Indonesia Tahun 1945 dan/atau undang-undang.

2) Pengaturan Administrasi Pemerintahan sebagaimana dimaksud pada ayat (1) mencakup tentang hak dan kewajiban pejabat pemerintahan, kewenangan pemerintahan, diskresi, penyelenggaraan administrasi pemerintahan, prosedur administrasi pemerintahan, keputusan pemerintahan, upaya administratif, pembinaan dan pengembangan administrasi pemerintahan, dan sanksi administratif.

Dari ketentuan di atas, dapat disimpulkan bahwa makna administrasi saat ini tidak hanya pada penyelenggara pemerintahan saja (eksekutif) tetapi juga kekuasaan lembaga negara yang lain. Disebutkan juga dalam Pasal 4 Ayat (1) di atas bahwa Badan dan/atau Pejabat Pemerintahan yang menyelanggarakan Fungsi Pemerintahan dalam lingkup lembaga legislatif dan yudikatif juga termasuk pada ruang lingkup administrasi.

Maka konsekuensi dari ketentuan di atas adalah, perkara yang akan di ajukan ke PTUN tidak hanya pada bidang penyelenggaraan pemerintahan oleh eksekutif 
saja seperti yang selama ini terjadi, tetapi juga pada bidang kekuasaan pemerintahan yang lain, yaitu yudikatif dan legislatif. Ketentuan ini sebenarnya menimbulkan permasalahan, karena bagaimana jika pada suatu ketika timbul permasalahan administrasi terjadi pada lembaga yudikatif sendiri, bagaimana keobjektifan PTUN akan memutus dan menyelesaikannya? Sementara itu sudah menjadi asal dalam hukum bahwa suatu lembaga tidak dapat mengadili dirinya sendiri. Jika hal ini dilakukan maka tingkat imparsialitas suatu lembaga sangat berpotensi terganggu.

\section{b. Mengadili Penyalahgunaan Wewenang}

Luasnya kewenangan pemerintah untuk mengintervensi kehidupan warga negara semakin membuka peluang terjadinya penyalahgunaan wewenang yang dilakukan oleh pejabat tata usaha negara. Negara kesejahteraan di satu sisi memang dapat melindungi masyarakat dari ketidakberdayaan menghadapi persaingan global namun di sisi lain juga bmembuka peluang terjadinya kesewenang-wenangan pejabat tata usaha negara. Oleh karena itu dibutuhkan perlindungan kepada warga negara dari kemungkinan terjadinya penyalahgunaan wewenang dari pejabat tata usaha negara ini, sehingga dalam UU ini mengatur pula kewenangan PTUN untuk memeriksa suatu Keputusan dan/atau Tindakan Pejabat Tata Usaha Negara mengandung penyalahgunaan wewenang atau tidak. Dalam UU No 5 Tahun 1986 hal ini belum di atur, sehingga penyalahgunaan wewenangan masih berada di Pengadilan Negari. Dalam Pasal 17 disebutkan:

1) Badan dan/atau Pejabat Pemerintahan dilarang menyalahgunakan Wewenang.

2) Larangan penyalahgunaan Wewenang sebagaimana dimaksud pada ayat

(1) meliputi:

a) larangan melampaui Wewenang;

b) larangan mencampuradukkan Wewenang; dan/atau

c) larangan bertindak sewenang-wenang.

Dalam Pasal 19, kembali dinyatakan:

1) Keputusan dan/atau Tindakan yang ditetapkan dan/atau dilakukan dengan melampaui Wewenang sebagaimana dimaksud dalam Pasal 17 ayat (2) huruf a dan Pasal 18 ayat (1) serta Keputusan dan/atau Tindakan yang ditetapkan dan/atau dilakukan secara sewenang-wenang sebagaimana dimaksud dalam Pasal 17 ayat (2) huruf c dan Pasal 18 ayat (3) tidak sah apabila telah diuji dan ada Putusan Pengadilan yang berkekuatan hukum tetap.

2) Keputusan dan/atau Tindakan yang ditetapkan dan/atau dilakukan dengan mencampuradukkan Wewenang sebagaimana dimaksud dalam Pasal 17 ayat (2) huruf b dan Pasal 18 ayat (2) dapat dibatalkan apabila telah diuji dan ada Putusan Pengadilan yang berkekuatan hukum tetap.

Kedua Pasal ini di atas secara eksplisit telah menyatakan bahwa Peradilan berhak untuk menyatakan suatu keputusan dan/atau tindakan pejabat tata usaha 
negara terdapat penyalahgunaan wewenang atau tidak di dalamnya. Kemudian semakin dipertegas kembali dalam Pasal 21, yaitu:

1) Pengadilan berwenang menerima, memeriksa, dan memutuskan ada atau tidak ada unsur penyalahgunaan Wewenang yang dilakukan oleh Pejabat Pemerintahan.

2) Badan dan/atau Pejabat Pemerintahan dapat mengajukan permohonan kepada Pengadilan untuk menilai ada atau tidak ada unsur penyalahgunaan Wewenang dalam Keputusan dan/atau Tindakan.

3) Pengadilan wajib memutus permohonan sebagaimana dimaksud pada ayat (2) paling lama 21 (dua puluh satu) hari kerja sejak permohonan diajukan.

4) Terhadap putusan Pengadilan sebagaimana dimaksud pada ayat (3) dapat diajukan banding ke Pengadilan Tinggi Tata Usaha Negara.

5) Pengadilan Tinggi Tata Usaha Negara wajib memutus permohonan banding sebagaimana dimaksud pada ayat (4) paling lama 21 (dua puluh satu) hari kerja sejak permohonan banding diajukan.

6) Putusan Pengadilan Tinggi Tata Usaha Negara sebagaimana dimaksud pada ayat (5) bersifat final dan mengikat.

Dapat diketahui dari ketentuan Pasal 21 di atas bahwa yang bewenang untuk menyatakan suatu keputusan dan/atau tindakan pejabat tata usaha negara terdapat penyalahgunaan wewenang atau tidak adalah Peradilan Tata Usaha Negara. Dengan demikian, kompetensi PTUN kembali bertambah luas, bahkan seperti yang telah dibahas sebelumnya bahwa yang dimaksud dengan Badan dan/atau Pejabat Pemeintah dalam UU ini tidak hanya pada bidang eksekutif saja, namun juga bidang legislatif dan yudikatif.

\section{c. Mengadili Diskresi Pejabat TUN}

Indonesia sebagai negara yang menjalankan prinsip kedaulatan rakyat (Pasal 1 ayat (2) UUD N RI Tahun 1945) berdasarkan atas hukum (Pasal 1 ayat (3) UUD N RI Tahun 1945) seperti yang telah penulis sampaikan di atas, melegitimasi bahwa Indonesia merupakan negara hukum. Konsekuensi dari pernyataan tersebut adalah segala tindakan dan kebijakan yang dikeluarkan oleh pemerintah harus sesuai dengan peraturan perundang-undangan. Segala kebijakan yang dikeluarkan tidak berdasarkan pada peraturan perundang-undangan dapat dikatakan sebagai perbuatan sewenang-wenang atau perbuatan tidak berwenang dan dapat dibatalkan demi hukum. Inilah konsepsi dasar pelaksanaan pemerintahan di Indonesia, namun karena keterbatasan dari asas ini atau karena adanya kelemahan dan kekurangan yang terdapat pada peraturan perundang-undangan itu sendiri, maka kepada pemerintah diberi kebebasan freies ermessen atau diskresi, yaitu kemerdekaan pemerintah untuk dapat bertindak atas inisiatif sendiri dalam menyelesaikan persoalan-persoalan sosial (Utrecht, 1988: 30). Menurut Ridwan HR, dalam praktik freies ermessen ini memebuka peluang terjadinya benturan kepentingan antara pemerintah dengan warga negara (Ridwan: 230).

Berkaitan dengan hal di atas, secara teoritis pertanggungjawaban terhadap diskresi sangat diperlukan. Mengingat penggunaan diskresi membuka peluang 
terjadinya penyalahgunaan wewenang oleh Pejabat TUN. Maka dalam UU ini pun sudah mengakomodir pengujian terhadap diskresi yang dikeluarkan oleh pejabat tata usaha negara. Jika di dalam diskresi itu terdapat unsur penyalahgunaan wewenang maka dapat dibatalkan dengan keputusan pengadilan. Dalam Pasal 30 UU ini disebutkan:

1) Penggunaan Diskresi dikategorikan melampaui Wewenang apabila:

a. bertindak melampaui batas waktu berlakunya Wewenang yang diberikan oleh ketentuan peraturan perundang-undangan;

b. bertindak melampaui batas wilayah berlakunya Wewenang yang diberikan oleh ketentuan peraturan perundang-undangan; dan/atau

c. tidak sesuai dengan ketentuan Pasal 26, Pasal 27, dan Pasal 28.

2) Akibat hukum dari penggunaan Diskresi sebagaimana dimaksud pada ayat (1) menjadi tidak sah.

Pasal 31

1) Penggunaan Diskresi dikategorikan mencampuradukkan Wewenang apabila:

a. menggunakan Diskresi tidak sesuai dengan tujuan Wewenang yang diberikan;

b. tidak sesuai dengan ketentuan Pasal 26, Pasal 27, dan Pasal 28; dan/atau

c. bertentangan dengan AUPB.

2) Akibat hukum dari penggunaan Diskresi sebagaimana dimaksud pada ayat (1) dapat dibatalkan.

Pasal 32

1) Penggunaan Diskresi dikategorikan sebagai tindakan sewenang-wenang apabila dikeluarkan oleh pejabat yang tidak berwenang.

2) Akibat hukum dari penggunaan Diskresi sebagaimana dimaksud pada ayat (1) menjadi tidak sah.

Perluasan kompetensi PTUN dalam menguji diskresi ini merupakan bentuk pergeseran doktrin lama yang menyatakan bahwa masing-masing kekuasaan dilarang untuk mengintervensi kewenangan kekuasaan lain. Eksekutif dilarang mencampuri urusan yudikatif dalam melakukan peradilan dan begitupun yudikatif dilarang mencampuri urusan pemerintahan dimana bidang pemerintahan adalah kewenangan eksekutif. Namun dalam negara modern sekarang ini, dimana peran negara diharapkan dalam seluruh aspek kehidupan masyarakat, maka untuk menghindari terjadinya penyalahgunaan wewenang, yudikatif diperbolehkan untuk mencampuri urusan eksekutif dalam rangka pengawasan dan perlindungan hak-hak warga negara.

\section{Probematika Pergeseran Kompetensi Absolut PTUN dalam UU No 30} Tahun 2014

Pergeseran kompetensi absolut Peradilan Tata Usaha Negara menimbulkan beberapa problematika, baik dalam tataran teori maupun aplikasinya di lapangan. Dalam pembahasan paper ini akan dikemukakan beberapa permasalahan berkaitan 
dengan peristilahan dan pelaksanaan UU tersebut, dikaitkan dengan perluasan kompetensi PTUN. Di antara beberapa problematika itu adalah sebagai berikut:

\section{a. Masih di Akuinya Eksistensi Upaya Administratif}

Salah satu problem yang masih ditimbulkan oleh UU No 5 Tahun 1986 adalah keberadaan upaya administratif yang dinilai mengurangi kewenangan PTUN. Sementara dari hampir semua upaya administratif yang dilakukan tidak ada yang menunjukkan keberhasilan upaya ini. Hal ini disebabkan oleh beberapa masalah yang terdapat dalam upaya administratif itu sendiri, yaitu: Ketiadaan hukum acara, kurangnya informasi, penilaian segi kebijaksanaan, penentuan batas waktu dan kurangnya fasilitas (Marbun: 103-104). Kemudian setelah upaya administratif dilakukan, PTUN tingkat pertama tidak lagi berhak untuk mengadilinya melainkan harus naik banding lansung. Pada UU No 30 Tahun 2014 ini, tidak mengatur mengenai penghapusan upaya administrasi sehingga keberadaan upaya administrasi masih tetap dibenarkan.

\section{b. Kekacauan Makna Peristilahan}

Dalam UU No 30 Tahun 2014 ini, banyak sekali digunakan istilah keputusan dan/atau tindakan. Ketentuan ini banyak mendapat kritikan dari ahli hukum administrasi. Frasa "keputusan dan/atau tindakan" memiliki makna rancu dan membingungkan, pasalnya secara teoritis tindakan adalah genus dari semua keputusan yang dikeluatkan oleh pejabat negara, baik dalam bentuk regelling, beshicking, izin, dan lain sebagainya. Maka apakah yang dimaksud dengan tindakan ini adalah termasuk semua keputusan itu atau tidak? Lalu mengapa menggunakan frasa "keputusan dan/atau tindakan", sementara keputusan adalah bagian dari tindakan itu sendiri? Dalam praktekpun hal ini akan menyulitkan PTUN dalam mengadili perkara, serta membuka peluang terjadinya penafsiran secara bebas yang hanya mengikuti kehendak golongan tertentu saja.

\section{c. Sumber Daya Manusia}

Sejak tahun 1986, kewenangan PTUN hanya terbatas pada beshicking dan sengketa kepegawaian, namun dengan UU No 30 Tahun 1984 ini kewenangan PTUN diperluas sedemikian rupa. Tentu saja dinamika ini akan berdampak pada sumber daya manusia yang dimiliki oleh PTUN, baik hakim, panitera, atau komponen lainnya. Para hakim dan panitera tentu dididik untuk menyelesaiakan perkara beshicking dan sengketa kepegawaian saja, karena memang untuk itulah PTUN dibentuk. Oleh karena itu, agar proses persidangan dapat berjalan dengan baik serta putusan berpihak pada keadilan harus dilakukan penyesuaian terlebih dahulu. Pada proses peradilan yang pertama UU ini, yaitu yang melibatkan PT TUN Medan dan pengacara kondang O.C. Kaligis ternyata menimbulkan masalah. Hakim dan pengacara terlibat kasus suap dan saat ini sedang diperiksa oleh KPK. Hal ini menandakan rentannya UU ini terhadap penyalahgunaan jika tidak dibarengi dengan perbaikan sumber daya manusia.

\section{d. Masalah Legal Standing}

Dalam Pasal 21 Ayat (2) disebutkan bahwa, Badan dan/atau Pejabat Pemerintahan dapat mengajukan permohonan kepada Pengadilan untuk menilai 
ada atau tidak ada unsur penyalahgunaan Wewenang dalam Keputusan dan/atau Tindakan. Kemudian semakin di jelaskan dengan keberadaan hukum acara dari UU No 30 Tahun 2014 ini yaitu dengan Peraaturan Mahkamah Agung (PERMA), dalam Pasal 2 PERMA ini, dinyatakan bahwa pemohon dalam penilaian ada atau tidak ada penyalahgunaan wewenang adalah badan dan/atau pejabat pemerintahan. Artinya yang berhak menjadi pemohon dalam UU ini hanyalah Badan dan/atau Pejabat Pemerintah.

Ketentuan ini sangat aneh, karena menghilangkan legal standing dari masyarakat biasa untuk melakukan pengujian, padahal masyarakatlah yang menjadi objek dari putusan pejabat tatausaha negara itu, dalam artian masyarakatlah yang menjadi korban atas penyalahgunaan wewenang tersebut. Maka seharusnya masyarakat juga diberikan kewenangan untuk menjadi pemohon.

\section{e. Kewenangan Mengadili Penyelengaraan fungsi yudikatif.}

Dalam UU No 30 Tahun 2014 ini, PTUN diberikan kewenangan untuk mengadili Badan dan/atau Pejabat Pemerintahan yang menyelenggarakan Fungsi Pemerintahan dalam lingkup lembaga yudikatif. Maka yang menjadi pertanyaan adalah apakah mungkin jika PTUN dapat dengan objektif mengadili perkara di lembaganya sendiri. Secara asas pun, kewenangan untuk mengadili diri sendiri ini tidak dibenarkan.

Demikianlah beberapa problematika yang muncul dari penerapan UndangUndang No 30 Tahun 2014 tentang Administrasi Pemerintahan. Kita menyadari bahwa tidak ada karya manusia yang sempurna di dunia ini, namun demikian analisis kritis terhadap suatu produk peraturan perundang-undangan tetap diperlukan demi terbentuknya sistem hukum yang lebih baik ke depannya.

\section{KESIMPULAN DAN SARAN}

1. Kesimpulan

a. Dalam UU No 5 Tahun 1986, PTUN hanya diberikan kewenangan untuk mengadili perkara beshicking dan sengketa kepegawaian saja. Namun karena semakin luasnya intervensi pemerintah terhadap kehidupan warga negara sebagai konsekuensi dari konsepsi negara kesejahteraan (walfare state), maka perlindungan terhadap warga negara dari penyalahgunaan wewenang yang dilakukan oleh Pejabat Tata Usaha Negara juga semakin diperketat. Langkah yang digunakan adalah menyediakan upaya hukum bagi masyarakat apabila ia merasa telah dirugikan oleh putusan pejabat TUN yang terdapat penyalahgunaan wewenang di dalamnya, termasuk dalam hal diskresi. Oleh karena itu, dalam UU No 30 Tahun 2014 kompetensi PTUN bergeser menjadi semakin luas, sehingga dapat memutus ada tidaknya penyalahgunaan wewenang dalam suatu Keputusan Tata Usaha Negara serta pengujian atas diskresi yang dikeluatkan oleh Pejabat Tata Usaha Negara.

b. Pergeseran kompetensi PTUN menimbulkan beberapa masalah, baik dalam peristilahan yang terdapat dalam UU maupun dalam upaya 
melaksanakannya. Problematika itu antara lain masih di akuinya eksistensi upaya administratif, kekacauan peristilahan "keputusan dan/atau tindakan" karena secara teoritis kedua istilah tersebut memiliki perbedaan yang sangat mendasar, Sumber Daya Manusia (SDM) yang dimiliki oleh PTUN (hakim, panitera dan yang lain) belum dididik untuk mengadili kompetensi absolut baru yang dimilikinya, yang memiliki legal standing dalam UU ini hanya Badan atau Pejabat TUN saja sedangkan masyakat biasa tidak, dan yang terakhir kewenangan untuk mengadili Badan dan/atau Pejabat Pemerintahan yang menyelenggarakan Fungsi Pemerintahan dalam lingkup lembaga yudikatif dapat dipertanyakan keobjektifan karena sama halnya dengan PTUN mengadili dirinya sendiri.

\section{Saran}

a. Kepada aparat penegak hukum (khususnya hakim PTUN) untuk dapat menyesuaikan sumberdaya manusia yang dimiliki agar dalam pelaksanaan UU No 30 Tahun 2014 ini tidak menemui banyak kendala.

b. Kepada pemerintah dan DPR selaku aktor pembuat UU untuk dapat menyesuaikan ketentuan norma (harmonisasi) antar satu perundangundangan dengan peraturan perundang-undangan lain agar tidak terjadi tumpang tindih norma.

\section{DAFTAR PUSTAKA}

Basah, Syachran (1992). Perlindungan Hukum atas Sikap Tindak Administrasi Negara, Bandung: Alumni.

Budiardjo, Miriam (1982). Dasar-dasar Ilmu Politik. Jakarta: Gramedia. Juniarto (1968). Negara Hukum. Yogyakarta: Yayasan Penerbit Gadjah Mada.

Lukman, Marcus (1982). Eksistensi peraturan kebijaksanaan dalam bidang perencanaan dan pelaksanaan Rencana Pembangunan di Daerah serta Dampaknya terhadap Pembangunan Meteri Hukum Tertulis Nasional. Bandung: Unpad.

Manan, Bagir (1985). Konvensi Ketatanegaraan. Jakarta: Pradnya Paramita Grafika. Marbun, S.F. (2011). Peradilan Administrasi Negara dan Upaya Administratif di Indonesia. Yogyakarta: UII Press.

(1988). Peradilan Tata Usaha Negara. Yogyakarta: Liberty.

Marbun, SF., dan MD., Mahfud (1987). Pokok-Pokok Hukum Administrasi Negara. Yogyakarta: Liberty.

Muchsan (1981). Beberapa Catatan tentang Hukum Administrasi Negara dan Peradilan Admiistrasi di Indonesia. Yogyakarta: Liberty.

Mustafa, Bachsan (2009). Pokok-Pokok Hukum Administrasi Negara. Yogyakarta.

Hadjon, Philip M. (1987). Perlindungan Hukum bagi Rakyat di Indonesia. Surabaya: Bina Ilmu.

et. al. (1993). Pengantar Hukum Administrasi Indonesia. Yogyakarta: UGM Press.

Ridwan HR (2011). Hukum Administrasi Negara. Jakarta: Rajawali Pers. 
Surayin (1992). Kamus Lengkap Inggris-Indonesia. Bandung: Armico.

(1992). Beberapa Hal tentang Hukum Acara Administrasi, Bandung: FH UNPAD.

Tjandra, W. Riawan (2009). Peradilan Tata Usaha Negara; Mendorong Terwujudnya Pemerintahan yang Bersih dan Berwibawa. Yogyakarta: Universitas Atma Jaya.

Utrecht (1988). Pengantar Hukum administrasi Negara Indonesia. Surabaya: Pustaka Tinta Mas.

Wiyono R. (2007). Hukum Acara Peradilan Tata Usaha Negara. Jakarta: Sinar. 